\title{
ЛІТЕРАТУР
}

1. Martin, P., 2004. Controlling the bread making process: the role of bubbles in bread. Cereal Foods World 49. pp. 72-75.

2. Sluimer, P., 2005. Principles of Breadmaking: Functionality of Raw Materials and Process Steps. American Association of Cereal Chemists, St. Paul. p. 212.

3. Fincher, G.B. and B.A. Stone. 1986. Cell wall and their components in cereal grain technology. In. Advances in Cereal Science and Technology. Pomeranz, Y. Ed. Am. Assoc. Cereal Chem., St.Paul, M.N. pp. 207-295.

4. Hoseney, RC., P. Wade and J.W. Finley. 1988. Soft wheat products. In Wheat Chemistry and Technology. Vol. 2. Pomeranz, Y. Ed. Am. Assoc. Cereal Chem. Inc. St. Paul, Minnesota, USA. pp. 407-456.

5. How Flour Affects Bread Quality. Lallemand Baking Update, Vol. 3, 17.

6. Weipert, D., 1997. Processing performance of rye as compared to wheat. Cereal Foods World, 42. pp. 706-712.

7. Pomeranz, Y. 1988. Chemical composition of kernel structures. In: Wheat Chemistry and Technology. Vol. 2. AACC International: St. Paul, MN. Pp. 97-158.

8. Dornez, E., K. Gebruers, S. Wiame, J. A. Delcour and C. M. Courtin. (2006). Insight into the distribution of arabinoxylans, endoxylanases, and endoxylanase inhibitors in industrial wheat roller mill streams. Journal of Agricultural and Food Chemistry, 54. pp. 8521-8529.

9. Sutton, K. H. and L. D. Simmons (2006). Molecular level protein composition of flour mill streams from a pilot-scale flour mill and its relationship to product quality. Cereal Chemistry, 83, 1. pp. 52-56.

10. Dewettinck, K., F. Van Bockstaele, B. Kuhne, D. Van de Walle, T. M. Courtens and X. Gellynck. (2008). Nutritional value of bread: Influence of processing, food interaction and consumer perception. Journal of Cereal Science, 48. pp. 243-257.

11. Pomeranz, Y. Wheat: Chemistry and Technology; American Association of Cereal Chemists: St. Paul, MN, 1988; Vol. II.

12. Villanueva, R. M.; Leong, M. H.; Posner, E. S.; Ponte, J. G. Split milling of wheat for diverse end-use products. Cereal Foods World 2001, 46. pp. 363-369.

13. Aprodu I., Banu I., Stoenescu G., Ionescu V. Effect of the Industrial Milling Process on the Rheological Behavior of Different. St Cerc St CICBIA. 2010;11(4). pp. 429-437.

14. Fistes A., Soronja Simovic D., Rakic D., Mastilovic J. Statistical evaluation of different wheat and flour quality tests for predicting end-use performance. Acta Aliment [Internet]. 2013; 42 (3). pp. 349-359.

Надійшла 02.02.2019. До друку 25.02.2019.

Рецензія 10.02.2019

Адреса для переписки:

65039, Odessa, str. Kanatnaya 112

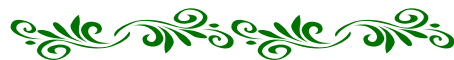

UDK 664.785

O.I. SHAPOVALENKO, Dr. tech. sc., professor National university of food technologies, Odessa, Ukraine

I.O. KUSTOV, PhD tech. sc., senior lecturer Odessa National Academy of Food Technologies, Odessa, Ukraine R.S. RIBCHINSKIY, the head of the public union "Millers of Ukraine"

\section{FEATURES OF CORN CONSUMPTION IN THE FOOD PRODUCTION INDUSTRY}

\begin{abstract}
Анотація
This paper presents the features of corn as raw material for groat industry. Corn is used in many segments of the food and processing industry. corn is processed for traditional food products - groats, flakes, flour, extruded foods, and other corn byproducts are widely used for the production of dry breakfast cereals, snacks, cereal bars. In terms of using of the advanced processing technologies, the industry produces starch, gluten, and germs. Corn germ is used to produce the high-value vegetable oil, as well as starch - for both food and non-food purposes. More than half (65\%) of corn is used for feed purposes, 25\%-technical purposes, and nearly 20\% - for various types of food production. corn is processed for traditional food products - groats, flakes, flour, extruded foods, and other corn by-products are widely used for the production of dry breakfast cereals, snacks, cereal bars. For the colour, corn is divided into white and yellow types. According to the literature data analysis, yellow corn is more used in China, Argentina, Brazil, while white corn - in some countries of Asia, Latin America, and the Balkan countries. Depending on its morphological features, the corn kernelis divided into various groups, species and subspecies.

In Ukraine corn kernel is classified into 8 types, with separately defined limitations on the content of the major crop in the batch, grains of other type, etc. Corn of I-VIII types with the quality indicators specified in the standard, for the production of food products. Flint and dent corn types are the most applied grain varieties in the industry, they are widely used in the production segment of food and feed products. Sweet corn is widely used as a vegetable crop in the food canning, food concentrates, starch and brewing industries due to its flavor properties. Popped corn is not only the most convenient raw material for the production of popcorn, but it also can be used as the raw material for the production of corn curls and dry breakfast cereals By analyzing the weight fraction of fat in kernels of different corn varieties we can note that the lowest number of fat is typical for popped corn (4.0\%) and the largest - for sweet corn (9.1\%); dent and flint corn have the same total fat number (4.5-4.9\%). Test weight of corn types - popped corn ranges within 712-826 g/l, dent corn - 875-893 g/l, and flint corn - 768-786 g/l. The weight of 1000 kernels of corn depending on the varieties changes within $150-600 \mathrm{~g}$.
\end{abstract}

Keywords: groat industry, corn, chemical composition, technological properties, processing. 
The grain industry is the leading one in the general agricultural production of Ukraine. For several recent years, the industry significantly strengthened its positions. At the same time, the upward trends in the production of grain crops led to some reorientation of the grain market for export trading of grains as raw materials. For more efficient using of grain resources, it makes sense to develop the domestic processing capacities, and the further exports of value-added grain by-products. In addition, modern technologies allow using the complex methods of grain crops processing to receive the wide range of finished products with the specified qualitative features.

Corn is one of the key crops in the grain segment of the Ukrainian crop production industry, which demonstrated the growth in production of 4.8 times for the recent decade.

In terms of the morphological structure and chemical composition of the kernel, for all seasons corn had a wide range of various applications. To date, the grain is mainly used as feed and industrial crop, to the smaller degree - food consumption, due to the presence of the well-developed raw material base in the form of modern selection varieties of buckwheat, rice, wheat, barley, oats, which to date form the major food potential of cereal crops.

Despite the low level of food consumption, on the global market corn is used in many segments of the food and processing industry. In South America, corn is used to produce tortillas, pancakes, couscous, porridges, etc. At the same time, in Africa and Asia corn is processed for groats, porridges, flour, and used in the production of various types of bread, fermented foods, snacks, alcoholic beverages, popcorn, non-alcoholic products, etc. [1]

At the same time, corn is processed for traditional food products - groats, flakes, flour, extruded foods, and other corn by-products are widely used for the production of dry breakfast cereals, snacks, cereal bars. In terms of using of the advanced processing technologies, the industry produces starch, gluten, and germs. Corn germ is used to produce the high-value vegetable oil, as well as starch — for both food and nonfood purposes. Also, corn is widely used for the production of alcohol. [2-3].

The wide range of corn application in various industries is the result of the growth of the share of its cultivation. According to the FAO (Food and Agriculture Organization of the United Nations) [4], in recent years the volumes of corn production in the world varied at the level of 870-1027 mlntonnes, while the share of planted areas remained almost unchanged and totaled 170-180 $\mathrm{mln}$ ha. Using of the prospective selection varieties of corn and the modern agricultural technologies provides the reporting increase in grain production.

The literature data analysis showed that in the world, corn takes the first position in production

volumes, but wheat and rice demonstrate the higher planted areas compared with the reporting grain. [5] The major planted areas are located in North America, but in recent years the share of corn areas started growing in South America, Europe, Asia and Africa. The USA, China, Canada, Brazil, Mexico, India and France are the global leaders in the production of corn, while Ukraine is one of the leaders of corn exports.

While analyzing the global consumption of corn provided by UkrAgroConsult [6], one may note that more than half $(65 \%)$ of corn is used for feed purposes, $25 \%$-technical purposes, and nearly $20 \%$ - for various types of food production.

For example, taking into account the share of corn consumption in the USA, it should be noted that the country uses only $1.5 \%$ of the general harvested volumes of the grain for foods production, as well as the feed purposes cover $42.5 \%$ of the grain volumes, the production of bioethanol $-31.2 \%$, the production of fructose syrup $-3.5 \%$, and the production of starch, sweeteners, alcoholic beverages, etc. $-6.2 \%$.[7]

In Ukraine, the production volumes of corn take the first position, and exceed the figures of wheat. At the same time, corn takes the third position in planted areas after wheat and barley. In Ukraine, the Steppe and the southern part of the Forest-steppe are the main regions of corn cultivation. For several recent years, the production volumes of corn in Ukraine demonstrated the most intensive growth rates compared with all other grain crops.

Corn groats in its pure form have rather low demand, and the structure of groats production is mainly represented by groats for the further production of more popular snack foods - flakes and curls. As for the production volumes in Ukraine, corn groats take the second position after buckwheat groats, which makes it possible to stress the large-scale consumer interest in the corn by-products in the country.

The advanced processing of corn at Ukrainian enterprises of the industry is rather limited, while starch is the major final product of such processing operations. The analysis of using of the similar technologies in developed countries, and the demand for corn byproducts received after the advanced processing 
operations, demonstrated the need to increase the share of such processing enterprises in the country, as well as increase the export potential of such products in the country.

As for the colour, corn is divided into white and yellow types. According to the literature data analysis, yellow corn is more used in China, Argentina, Brazil, while white corn - in some countries of Asia, Latin America, and the Balkan countries. [7] Also, there are found corn grain varieties with orange, red, dark-cherry, black and purple colour, but their share is much less in comparison with white and yellow corn.

Depending on its morphological features, the corn kernelis divided into various groups, species and subspecies. To date, scientists already specified such subspecies of corn: flint corn (Zea mays indurata Start.); dent corn (Zea mays indentata Start.); flint-dent corn (Zea mays semidentata Sturt.); flour corn (Zea mays amylacea Sturt.); popped corn (Zea mays everta Sturt.); sweet corn (Zea mays saccharata Sturt.); waxy corn (Zea mays ceratinaKulesch.); starch-sweet corn (Zea mays amyleo-saccharata Sturt.); and pod corn (Zea mays tunicata Sturt.). [8]

According to various botanical \& biological characteristics of the grain colour and shape, in Ukraine corn kernel is classified into 8 types, with separately defined limitations on the content of the major crop in the batch, grains of other type, etc. In terms of exceeding of the regulated standards of keeping of non-basic type of crops in one grain batch, the following batch is classified as the 9th certain type - "mixture of types". At the same time, in the territory of Ukraine pod and starch-sweet corn types are rather noncharacteristic. Pod corn does not have any industrial potential, so it is almost not used for the production of any type of foods, while starch-sweet corn is grown in the countries of South America only.

According to the DSTU 4525:2006 [9], it is recommended to use corn of I-VIII types with the quality indicators specified in the standard, for the production of food products.

While analyzing the figures of the average storehouse and experience of corn consumption in grain processing enterprises, it can be noted that flint and dent corn types are the most applied grain varieties in the industry, they are widely used in the production segment of food and feed products. Osokina N.M. [10] and others reported that it makes the most sense to use dent and semi-dent types of corn for the production of small groats, which are further used as the raw materials for corn curls. According to Salo O.S. [11], popped corn is not only the most convenient raw material for the production of popcorn, but it also can be used as the raw material for the production of corn curls and dry breakfast cereals.

According to the analysis of the usage of other types of corn in the production of food products, sweet corn is widely used as a vegetable crop in the food canning, food concentrates, starch and brewing industries due to its flavor properties, which waxy corn is the raw material for the production of amylopectin starch. [12]

According to the literature data analysis, in Ukraine there is rather significant share of both domestic and foreign varieties and hybrids of corn that are applicable for the cultivation and distribution throughout the territory of the country. For several recent years demonstrates the constant increase in the number of hybrids and varieties of corn in Ukraine. For example, in 1996 their number totaled 153, in 2012 - 621, in 2013 - 674, in 2015 - 750, and in 2016 - more than 1000.

The endosperm forms the largest share of grain kernel in corn, which covers the major weight fraction of starch (nearly 98\%). According to BeMiller J.N. [13], the germ covers nearly $65 \%$ of sugars. According to Chakraverty A. and others [14], the grain shell covers nearly $70 \%$ of hemicellulose, $23 \%$ of cellulose and $0.1 \%$ of lignin.

The weight fraction of proteins, and their composition are one of the most important factors that should be taken into account in terms of choosing of the certain grain type as the raw material for the production of high-quality human food products. In terms of manufacturing of high-quality products for the adequate nutrition, it is advisable to ensure the presence in the products of all essential amino acids for the human body: lysine, tryptophane, methionine, threonine, valine, phenylalanine, leucine, isoleucine. Improving of the qualitative characteristics of the protein content is one of the major direction of corn for grain selection and hybridization. For recent 35-40 years, the world worked out the high-protein varieties and hybrids of corn, which are cultivated throughout the large-scale areas of China, South and North America, etc.

Taking into account the research figures, we can stress the figures by BeMiller J.N. [13], who specified the significant fluctuations in protein content of the kernel within the range of $6-16 \%$, caused by various varietal features and agro-climatic conditions of vegetation. At the same time, while comparing dent and flint corn one can note almost equal weight fraction of protein within $9-14 \%$ [15]. At the same time, the figures by Ghosh T.K.and Prelas M.A. [16] for popped corn demonstrate the weight fraction of protein in the kernel at nearly $15 \%$.

Domaretsky V.A. [17] noted that according to the solubility criterion, corn proteins include $60 \%$ of prolamins, $38 \%$ of glutelins, $14 \%$ of albumins, and $22.6 \%$ of globulins. The alcohol-soluble fraction of proteins (prolamine) in corn kernel has the name "zein", and it is the inherent part of protein, which can be potentially applied in many industries due to its excellent properties, for example in the production of fibers, ceramics, textile fabrics, chewing gum, biodegradable plastic polymers, etc.

The placement of proteins in corn kernel in the endosperm and germ parts makes the certain differences in their fractional composition. For example, according to Applewhite T.H. [18] the proteins which are located in the endosperm, include $3 \%$ of nonprotein nitrogen, $3 \%$ of albumins, $3 \%$ of globulins, $60 \%$ of prolamins, $26 \%$ of glutelins, while the proteins located in the germ parts are characterized with $20 \%$ of nonprotein nitrogen, $35 \%$ of albumins, $19 \%$ of globulins, $5 \%$ of prolamins, and $18 \%$ of glutelins.

Domaretsky V.A. [17] reported that corn proteins are composed of 18 nonessential and essential amino acids, including such major ones as asparaginic acid, 
alanine, arginine, cysteine, glutamic acid, glycine, histidine, isoleucine, leucine, lysine, etc.

As for the distribution of amino acids by protein fractions, we can give the figures by Zarkadas C.G. and others [19] that show the zein fraction of corn proteins is characterized with the high share of amino acids: leucine, proline, glutamic acid, while lysine and tryptophane are almost absent. Corn kernel is characterized by the presence of the massive germ which can cover nearly $15 \%$ of the kernel weight. At the same time, the reporting part of grain is not used in the groats, food concentrates and starch industries due to the high weight fraction of fat (nearly 80\%) and its instability, which causes the need of its removal. In such case, the corn germ is used for the production of corn oil. Fats are located in almost all anatomical parts of corn kernel.

Herewith, the general weight fraction of fat for the common industrial varieties and hybrids of corn varies within $4-5 \%$. Today, the breeding and the hybridization result from the emerging of corn with the high weight fraction of fat in kernel (12-20\%) The fat in corn kernels are set in the form of drops with the diameter approximately 1.3 micron. [20]

By analyzing the weight fraction of fat in kernels of different corn varieties we can note that the lowest number of fat is typical for popped corn $(4.0 \%)$ and the largest - for sweet corn $(9.1 \%)$; dent and flint corn have the same total fat number $(4.5-4.9 \%)$. [21] If we look at the distribution of the fatty acids by anatomical parts of kernels it can be noted that the fats in blossom parts have the low number of mass fraction of palmic acid and the high fraction of oleic and linoleic acids. The fats in endosperm cell typically have the high fraction of palmic and linoleic acids and low weight fraction of linoleic and oleic acids. [22]

By analyzing the soluble carbonhydrates in different varieties of corn we can distinguish that dent and flint corn have almost the same part of soluble carbonhydrates (up to $80 \%$ ), popped and sweet corn have less $(74-78 \%)$. The starch is the main compound of the carbohydrate complex of corn and most cereals and the weight fraction depending on varieties can total $72 \%$. [21]

The starch in corn is placed in the form of lensshaped, spherical and concave shaped granules with the diameters from 2 till 30 microns. The starch granules of common kernel comprise $70-80 \%$ of amylopectin and $20-30 \%$ of amylose, the granules of wax-varieties comprise $100 \%$ of amylopectin, and high amyloze varieties - 50-90\% of amylose. [23, 24] Among the traditional varieties of corn, the lowest starch weight fraction is typical for sweet corn $-54 \%$. Dent corn has $64-78 \%$ of starch. [25] The temperature interval for the gelatination of starch in corn kernels comprises 88-93\%. $[26,27]$

The weight fraction of cellulose in kernels of corn usually totals $2 \%$. The vast majority of the substances indigestible by the body are in the upper shell portion of kernels - nearly $70 \%$ of hemicellulose, $23 \%$ of cellulose and $0.1 \%$ of lignin. [28] The pentosans weight fraction in corn kernels totals $5-8 \%$, herewith their largest fraction $30-40 \%$ is characterized for the upper shell portion of kernels, the lowest number $0.5-3.0 \%$ - for endosperm. [29]

The weight fraction of sugars in corn kernels totals nearly $1-3 \%$. [23] The kernels contain saccharose, glucose, maltose, fructose, galactose, cellobiose, ribose, mannose and xylose. [25] The sweetening agents are unevenly distributed in anatomical parts of corn kernels. The smallest weight fraction of the agents are in endosperm $0.2-0.5 \%$ and the largest $9.4-$ $11.3 \%$ - in germinal parts. The shell parts contain $0.3-$ $1.0 \%$ of sweetening agents. [30]

The ash number of corn kernels varies within 1.5$3.0 \%$, herewith, $70 \%$ of the total ash elements are situation in germinal parts. [23] Looking at the total weight fraction of ash in corn kernels we can note the data by Bajaj Y.P.S. [21] who distinguishes almost the same numbers for dent and sweet corn - up to $2.0 \%$, the lower ash weight fraction is common for the popped and flint corn $-1.6-1.7 \%$. The weight fraction of ash in endosperm totals nearly $0.7-1.1 \%$, in germinal part -31 $39 \%$, shell parts $-0.7-1.2 \%$ [30].

Analyzing the distribution of the mineral elements in accordance with the anatomic parts of kernel it can be distinguished that the germinal and shell parts contain the largest weight fraction of mineral elements, whereas endosperm contains mostly Iron, Calcium, Zinc, etc.

According to Larkins B.A. [31] the kernels of corn have such vitamins as A, E, K,antidermatitis vitamin, niacin, pyridoxine and folic acid, alpha tocopherol (E), pantothenic acid. If we analize the content of vitamins in yellow corn listed by Gwirtz J. A. and others [32] we can note that the germinal parts contain B-complex vitamins and the antioxidant (E vitamins), the upper layers of the kernel contain the soluble vitamins, the starch does not have vitamins (excluding holing) that demonstrates the low content of the vitamins in endosperm. By analyzing the research of the vitamins content (38-40) we can distinguish that corn kernels have high total weight of antioxidants carotenoids.

By the characteristics of endosperm the corn kernels are divided into dent, flint, popped and sweet corn, etc. All the types of corn kernel are characterized by the endosperm of white color, but the shell parts in comparison with other crops have the wider color rage from typical light white and yellow to red and black shades, herewith, the corn kernels with white and yellow shades are more preferable in food industry. [33, 34]

Depending on the types the dent corn kernel has yellow, white or red coloring, the flint corn kernel is mostly white and yellow, sweet and popped corn are white. [8]

According to the analysis of the DSTU (National Standards of Ukraine) 4525-2006 [9] we can note that the corn kernels are characterized by the prolonged, round, beak shape with pressed or sloped sides, the top of the kernel is round and pressed.

If we look at the types of corn separately, we can note that the majority of flint grains used in the production the kernels have the round smooth top and the pressed sides, the dent corn has prolonged kernels with non-homogeneous top (in the form of tooth), and popped 
corn has prolonged narrowed kernel (in the form of beak). [35-37]

In terms of the production of groats products the geometrical characteristics of kernels and their size are the most important. The correct evaluation of the geometrical characteristics of kernels regardless of the crop allows to provide the reasonable forming of the technological processes, which is especially important during the cleaning of kernels from dockage and the specification of the milling when eliminating the germinate.

The kernel size at the food production is an important characteristics because the processing of bigger and full kernel allows to receive bigger volumes of the finished products, moreover, the bigger sized kernels have more useful elements for humans which allows to get more quality food product. Also, in terms of productivity the processing of the small and hollow kernels is not advantageous. Because of this, there is a restriction in theshare of small kernels for food use for the majority of the traditional crops - with accordance to the current standardstheweight fraction must not exceed $5 \%$, and it is determined by the passover of the standardized sieve. The rise of the corn kernels is usually determined as the ratio of kernels weight in the passover of the sieve $\varnothing 8 \mathrm{~mm}$ to the weight of the main kernels in $\%$. With accordance to the current standard the kernels of corn are considered hollow if they went though the sieve $\varnothing 4.5 \mathrm{~mm}$ and are received the sieve $1.2 \times 20 \mathrm{~mm}$, herewith, the size of the kernels for use must be not less than $80 \%$. According to the analysis the literature it can be noted that the dent corn type is characterized as the largest by size, flint corn - as large or small, and popped corn - as small. Considering the size of the kernels of flint corn Kulakova E.V. [38] showed that this type of corn is characterized by the high size numbers $-86-89 \%$.

According to the geometrical characteristics among the other crops corn has the largest size - 8-17 $\mathrm{mm}$ in length and 5-15 $\mathrm{mm}$ in width. As Briggs D.E. [39] shows kernels of dent corn has $12 \mathrm{~mm}$ in length, $8 \mathrm{~mm}$ in width and $4 \mathrm{~mm}$ in thickness. Exploring the influence of the weight fraction of moisture on the change of physical properties of popped corn Karababa E. [40] found that the increase of moisture in kernels has little affect on the size change of this kernels: 8.2-9.2 mm in length, 5.7-6.3 $\mathrm{mm}$ in width and 3.7-4.9 $\mathrm{mm}$ in thickness.

The important figure of the physical property of kernels in groats production is the test weight of 1000 of kernels. The weight of 1000 kernels of corn according to data by Kent N.L. [41] depending on the varieties and the agro-climatic conditions changes within 150-600 g. If we analyze the limit of this figure on behalf of different types of corn we can note that the largest figures are typical for flint corn - 250-400 g, smaller for flint types 150-300 g, and the smallest for popped corn - 100-150 g. [8] The test weight of corn kernel is also distinguishes the maturity and the hardness of kernels, with the average number totaling $720 \mathrm{~g} / \mathrm{l}$. [30] If we analyze the test weight in terms of corn types we can state that popped corn's figure ranges within 712-826 g/1 [42], dent corn 875-893 g/l, and flint corn - 768-786 g/1. [43]

We can separate four main ways of corn processing: groats production, starch-molasses production, ethanol production, and the feed production.

In terms of the food use of corn, the processing process involves corn groats production only. The current technologies on Ukraine provide the next assortment of groats: large groats for flakes and puffers, small groats for the production of corn curls,polished groats and milled groats. [44]. During the production of corn groats the manufacturers also receive corn flour and germinate which can be used for the production of corn oil.

The stash production is the main approach of the deep corn processing in Ukraine. The main by-products of corn are starch and gluten. At the same time, the starch is used for the manufacturing of dextrin, maltose, molasses etc. Also the products of starch-mollases productionare used in biochemical production of lemon acid and monosodium glutamate. Corn germinate and corn screening are the by-products of starch-mollases production.

One of the most perspective ways of the corn processing is the production of bioethanol that allows receiving the power resource - the biofuel made from the sustainable raw material, and also the valuable feed additive DDG, which is widely used in feed milling. $[45,46]$

In order the process the corn kernels into groats and flour, it is necessary to remove the germ. The international experience shows different technologies of corn processing. Today there are two methods of germ separation: dry and wet. The majority of the plants in our country use dry method via using the special machines of rubbing type- germ separators (the machine for the dry germ separation), that allows to simultaneously mill corn kernels for $5-8$ parts and separate $95 \%$ of germs. The drawback of this method is that during the separation the germ is milled and mixed with the peripheral parts of corn and with the flour, which appears when milling. Here, instead of using $8-10 \%$ of this germ in food industry, it is mixed with flour and then sold as a feed flour. Thus the cost of corn germ on the market of Ukraine and Russia equals to the prices of the groat which is twice higher compared to the feed flour. [44-46]

The use of water-thermal treatment gives an advantage not only over the grain handling on the following processes of milling and polishing, but also facilitates the separation of germ and its preservation integrally. The germ connected with the endosperm with the help of the bark does not have the cellular structure and consist of the protein and pentosans. As a result of the damping, this bark is softened and the connection with endosperm decreases. This method is better if the germ is used further as the raw material for the production of oils. The germ that usually has high content of fat is an excellent raw material for the production of edible oils and is rich by unsaturated fatty acids, phosphotides, tocopherol and other bioactive substances. As a result, the germ needs to be separated from the kernel after which the content of the endosperm must be minimal. After the water-thermal treatment of corn with an optimum performance it is possible to receive best possible conditions: the germ is released in the form of larger parts and contain less endosperm, which improves the quality of oils. [68, 71] 
This technology is especially needed for the production of groats for flakes and corn curls, because the shell is easier to remove during the milling process, and the endosperm is shredded for bigger parts that are necessary for the production of flakes. For today, this technology is widely used for the production of corn starch. [44, 47]
Considering the analysis of literature, it would seem appropriate to provide a comprehensive study of the condition of the corn food processing industry in Ukraine and advice provision concerning the prospects of development of this segment. One of the main areas of development is desirable to adopt improvement of the current technological production system.

\section{REFERENCES}

1. Serna-Saldivar, S. O. Food uses of whole corn and dry-milled fractions Corn. [Text] / S. O. Serna-Saldivar, E. P. Carrillo. - AACC International Press, 2019. - p. 435-467.

2. Inglett, G. Maize: Recent Progress in Chemistry and Technology[Text] / G. Inglett. - Elsevier, 2012. - 262 p.

3. Igoe, R. S. Dictionary of food ingredients [Text] / R. S. Igoe . - Springer Science \& Business Media, 2013. - $201 p$

4. Prodovolstvennaya i selskohozyajstvennaya organizaciya Obedenennyh nacij [Elektronnij resurs]. - rezhim dostupu: http://www.fao.org/home/ru/

5. Moskvichev, A. Yu. Effektivnost sposobov osnovnoj obrabotki i sredstv himizacii na zernovuyu produktivnost kukuruzy na chernozemnyh pochvah Volgogradskoj oblasti [Tekst] / Moskvichev A. Yu. i dr. I/ Izvestiya Nizhnevolzhskogo agrouniversitetskogo kompleksa: nauka i vysshee professionalnoe obrazova-nie. - 2013. - №. 4 (32).

6. Analitika Ukragrokonsalt [Elektronnij resurs]. - rezhim dostupu: http://www.ukragroconsult.com/analytics?id=all

7. Hammond, B. G. Impact of food processing on the safety assessment for proteins introduced into biotechnology-derived soybean and corn crops [Text] / B. G. Hammond, J. M. Jez // Food and Chemical Toxicology. - 2011. - vol. 49. - №. 4. p. 711-721.

8. Zinchenko, O.I. Roslinnictvo [Tekst]/ O.I. Zinchenko, V.N. Salatenko, M.A. Bilonozhko. - K.: Agrarnaosvita, 2001. - 591 s.

9. Corn. Specifications: DSTU 4525: 2006. - [Valid from 2007-04-01]. - K.: State Committee of Ukraine, 2007. - 15 p. (National Standard of Ukraine).

10. Osokina, N. M Tehnologichni vlastivosti zerna gibridu kukurudzi PR39B58 [Tekst] / N. M. Osokina, K. V. Kostecka, Ya. V. Yevchuk // Zbirnik naukovih prac Umanskogo nacionalnogo universitetu sadivnictva. - 2014. - №. 86 (1). - S. 37-43.

11. Salo, O. S. Innovacijni napryami selekciyi specializovanoyi kukurudzi v Instituti roslinnictva im. VYa Yur'yeva UAAN [Tekst] //Visnik CNZ APV Harkivskoyi oblasti.-2009.- T. 6. - S. 131-137.

12. Koptelova, E. K. O krahmale iz voskovidnoj kukuruzy [Tekst] / E. K. Koptelova, N. D. Lukin, Yu. I. Tretyakov //Pishevaya promyshlennost. - 2012. - №. 4. - S. 56-58.

13. BeMiller, J. N. Starch: Chemistry and Technology [Text] / J.N. BeMiller, R.L. Whistler. -Academic Press, $2009 .-894$ p.

14. Chakraverty, A. Handbook of Postharvest Technology: Cereals, Fruits, Vegetables, Tea, and Spices [Text] / A. Chakraverty, A. S. Mujumdar, H. S. Ramaswamy. - CRC Press, 2003. -912 p.

15. Philippeau, C. Relationship between ruminal starch degradation and the physical characteristics of corn grain [Text] $/$ Philippeau C. et al. // Journal of animal science. - 1999. - vol. 77. - №. 1. - p. 238-243.

16. Ghosh, T.K. Energy Resources and Systems: Volume 2: Renewable Resources [Text] / T.K. Ghosh, M.A. Prelas. - Springer Science \& Business Media, 2011. - 727 p.

17. Domareckij, V. A. Tehnologiya ekstraktiv, koncentrativ i napoyiv iz roslinnoyi sirovini.: Pidruchnik dlya VMNZ III-IV r.a. [Tekst] - Nova Kniga. - 370 c.

18. Applewhite, T. H. Proceedings of the World Congress on Vegetable Protein Utilization in Human Foods and Animal Feedstuffs [Text] / T. H. Applewhite. - The American Oil Chemists Society, 1989.

19. Zarkadas, C. G. Assessment of the protein quality of 15 new northern adapted cultivars of quality protein maize using amino acid analysis [Text] / C. G. Zarkadas et al. //Journal of agricultural and food chemistry. - 2000. - vol. 48. - №. 11. p. 5351-5361.

20. Lásztity R. Cereal Chemistry [Text] / R. Lásztity. - International Specialized Book Services, 1999. - 307 p.

21. Bajaj, Y.P.S. Maize, Biotechnology in Agriculture and Forestry [Text] / Y.P.S. Bajaj . -Springer Science \& Business Media, 2012. $-632 p$.

22. Meurant, G. Lipids in cereal technology[Text] /. Elsevier, 2012. - 425 p.

23. Wrigley, C. W. Encyclopedia of food grains [Text] / C. W. Wrigley, H. Corke, K. Seetharaman, J. Faubion. - Academic Press, 2015. - 1976 p.

24. Belitz, H.-D. Food Chemistry [Text] / H.-D. Belitz,W. Grosch, P. Schieberle. - Springer Science \& Business Media, 2013. $-993 p$

25. Kulp, K. Handbook of Cereal Science and Technology [Text] / K. Kulp. -CRC Press, 2000. -808 p.

26. Malin, S. Starch in Food: Structure, Function and Applications [Text] / S., Malin, L. Nilsson. - Woodhead Publishing, 2017. $-916 p$.

27. Ahmed J. Novel food processing: effects on rheological and functional properties[Text] /. - CRC Press, 2016. - 510 p.

28. Inglett, G.Maize: Recent Progress in Chemistry and Technology [Text] /. - Academic Press, 2012.- 262 p.

29. Y. H. Hui, F. Sherkat Handbook of Food Science, Technology, and Engineering 4Volume Set [Text] / Y. H. Hui, F. Sherkat. - CRC Press, 2005. - $3632 p$.

30. Henry, R. J. Cereal Grain Quality [Text] / R. J. Henry, P. S. Kettlewell. - London UK: Chapman and Hall, 1996. -488p.

31. Larkins, B. A. Maize Kernel Development [Text] /. - CABI, 2017. - 253 p.

32. Gwirtz, J. A. Processing maize flour and corn meal food products [Text] / J. A. Gwirtz, M. N. Garcia-Casal//Annals of the New York Academy of Sciences. - 2014. - vol. 1312. - №. 1. - p. 66-75.

33. Lasztity R. The chemistry of cereal proteins [Text] \%. - Routledge, 2017. - $336 p$.

34. Liu, K. Distillers Grains: Production, Properties, and Utilization [Text] / K. Liu, K. A. Rosentrater. - CRC Press, 2016 .$564 \mathrm{p}$.

35. Fadeev, L. Kukuruza. Osobennosti stroeniya [Tekst]. - Hranenie i pererabotka zerna. - 2015. - T. 192. - №. 3-4. S. 41-43. 
36. Yahtanigova, Zh. M. Himicheskij sostav i pitatelnaya cennost zerna i listostebelnoj massy razlichnyh podvidov kukuruzy [Tekst]. - Novye tehnologii. - 2008. - №. 5 .

37. Sotchenko Yu. V. Issledovanie himicheskogo sostava zerna perspektivnyh samoopylennyh linij kukuruzy [Elektronnij resurs]. - rezhim dostupu:http://bibl-stgau.ru/images/Files/number29.pdf\#page $=220$

38. Kulakova, E. V. Contribution to the investigation of the corn germ Part I. Corn germ as a valuable source of protein [Text] / E. V. Kulakova, E. S. Vainerman S. V. Rogoshin// Molecular Nutrition \& Food Research. - 1982. - vol. 26. - №. 5. - p. 451-456. doi.org/10.1002/food.19820260508

39. Briggs, D. E. Malts and malting [Text]. - Springer Science \& Business Media, 1998. - 796 p.

40. Karababa, E. Physical properties of popcorn kernels. - Journal of Food Engineering. - 2006. - vol. 72. - №. 1. - p. 100107. doi:10.1016/j.jfoodeng.2004.11.028

41. Kent, N.L. Technology of cereals: an introduction for students of food science and agriculture [Text] / N.L. Kent, A.D. Evers. - Woodhead Publishing, 1994. - 334 p.

42. Hallauer, A. R. Specialty Corns, Second Edition [Text] / A. R. Hallauer. - CRC Press, 2000. -496 p.

43. Scrob, S. The biochemical composition and correlation estimates for grain quality in maize [Text] / Scrob S. et al. //Journal of Agroalimentary Processes and Technologies. - 2014. - vol 20. - №. 2. - p. 150-155.

44. Shutenko Ye.I. Tehnologiya krup'yanogo virobnictva: navch. posibnik/Ye.I. Shutenko, S.M. Soc.- K.: Osvita Ukrayini, 2010. $-272 s$.

45. Ray, R.C. Bioethanol Production from Food Crops: Sustainable Sources, Interventions, and Challenges [Text] / R.C. Ray, S. Ramachandran. - Academic Press, 2018. - 460 p.

46. Thorne, P.J. Maize as Food, Feed, and Fertiliser in Intensifying Crop-livestock Systems in East and Southern Africa: An Ex Ante Impact Assessment of Technology Interventions to Improve Smallholder Welfare [Text]. - ILRI, 2002. - 112 p.

47. Egorov, G.A Tehnologiya muki. Tehnologiya krupy [Tekst] / G.A. Egorov, N.V. Kurkina, G.C. Cybikova, i dr. - Moskva: KolosS, 2005. - 296 c.

О.И. ШАПОВАЛЕНКО, д-р техн. наук, професор Національний університет харчових технологій, м. Киї И.О. КУСТОВ, канд.техн.наук, доцент Одеська національна академія харчових технологій, м.Одеса Р.С. РИБЧИНСЬКИЙ, голова громадської спілки «Борошномели України»

\section{ОСОБЛИВОСТІ ВИКОРИСТАННЯ КУКУРУДЗИ ПРИ ВИРОБНИЦТВІ ХАРЧОВИХ ПРОДУКТІВ}

\section{Анотація}

У статті представлені особливості застосування кукурудзи як сировини для круп'яної промисловості. Кукурудза використовується в багатьох сегментах харчової та переробної промисловості. кукурудзу переробляють для традиційних харчових продуктів - крупи, пластівиі, борошно, екструдовані продукти та інші побічні продукти кукурудзи широко використовуються для виробництва сухих сніданків, снеків, зернових батончиків. 3 точки зору використання передових технологій переробки промисловість виробляє крохмаль, глютен $і$ зародок. Кукурудзяний зародок використовується для виробництва високоцінного рослинного масла, а також крохмалю - як для харчових, так і нехарчових иілей. Більше половини (65\%) кукурудзи використовується для кормових иілей, 25\% - технічних иілей, $і$ майже 20\% - для різних видів виробництва продуктів харчування. Кукурудзу переробляють у традиџійні харчові продукти - крупи, пластівці, борошно, екструдовані продукти та інші. За кольором кукурудзу поділяють на білу $і$ жовту. Жовта кукурудза частіше використовується в Китаї, Аргентині, Бразилії, а біла кукурудза - в деяких країнах Азї, Латинської Америки та балканських крайнах. Залежно від морфологічних особливостей, кукурудза поділяється на різні групи, види і підвиди.

В Україні зерно кукурудзи відповідно до ботанічних, біологічних ознак за кольором та формою зерна класифікують на 8 типів, при изьому окремо визначено обмеження щуодо вмісту у партії основного зерна, зерен іншого типу. Кукурудзу I-VIII типів рекомендовано використовувати для виробництва продуктів продовольчого призначення із показниками якості визначеними у стандарті. Найбільш використованими у галузі є кремениста та зубовидна кукурудза, їх широко використовують для виробництва продовольчих та кормових продуктів. Цукрова кукурудза завдяки своїм смаковим властивостям використовується як овочева культура, при цьвому вона широко застосовується у консервній, харчоконцентратній, крохмале-патоковій та пивоварній промисловості. Розлусна кукурудза є не тільки підходящою сировиною для виробництва «повітряної» кукурудзи (попкорну), а і може застосовуватися як сировина для виробництва паличок та сухих сніданків. Аналізуючи вагову частку жиру в ядрах різних сортів кукурудзи, можна відзначити, щяо найменша кількість жиру характерна для розлусної кукурудзи (4,0\%), а найбільша - для иукрової кукурудзи (9,1\%); зубовидна та кремниста кукурудза мають приблизно однакову загальну кількість жиру (4,5-4,9\%). Натура зерна кукурудзи - розлусної знаходиться в діапазоні 712-826 г/л, зубовидної - 875-893 г/л, кремнистої - 768-786 г/л. Маса 1000 зерен кукурудзи в залежності від сортових особливостей змнюється в діапазоні 150-600 2.

Ключові слова: круп'яна промисловість, кукурудза, хімічний склад, технологічні властивості, переробка. 


\section{ЛITEPATУРA}

1. Serna-Saldivar, S. O. Food uses of whole corn and dry-milled fractions Corn. [Text] / S. O. Serna-Saldivar, E. P. Carrillo. - AACC International Press, 2019. - p. 435-467.

2. Inglett, G. Maize: Recent Progress in Chemistry and Technology[Text] / G. Inglett. - Elsevier, 2012. - $262 p$.

3. Igoe, R. S. Dictionary of food ingredients [Text] / R. S. Igoe . - Springer Science \& Business Media, 2013. - $201 p$

4. Продовольственная и сельскохозяйственная организация Объедененных наций [Електронний ресурс]. - режим docmyny: http://www.fao.org/home/ru/

5. Москвичев, А. Ю. Эффективность способов основной обработки и средств химизачии на зерновую продуктивность кукурузы на черноземных почвах Волгоградской области [Текст] / Москвичев А. Ю. и др. // Известия Нижневолжского агроуниверситетского комплекса: наука и высшее профессиональное образование. - 2013. - №. 4 (32).

6. Аналитика Украгроконсалт [Електронний ресурс]. - режим доступу: http://www.ukragroconsult.com/analytics? id $=$ all

7. Hammond, B. G. Impact of food processing on the safety assessment for proteins introduced into biotechnology-derived soybean and corn crops [Text] / B. G. Hammond, J. M. Jez // Food and Chemical Toxicology. - 2011. - vol. 49. - №. 4. p. 711-721.

8. Зінченко, О.І. Рослинництво [Текст] / О.І. Зінченко, В.Н. Салатенко, М.А. Білоножко. - К.: Аграрнаосвіта, 2001. $591 \mathrm{c}$.

9. Corn. Specifications: DSTU 4525: 2006. - [Valid from 2007-04-01]. - K.: State Committee of Ukraine, 2007. - 15 p. (National Standard of Ukraine).

10. Осокіна, Н. М Технологічні властивості зерна гібриду кукурудзи ПРз9Б58 [Текст] / Н. М. Осокіна, К. В. Костеиька, Я. В. Свчук // Збірник наукових праць Уманського національного університету садівництва. - 2014. - №. 86 (1). - C. 37-43.

11. Сало, О. С. Інноваційні напрями селекції спеціалізованої кукурудзи в Інституті рослиннищтва ім. ВЯ Юр'єва УААН [Текст] //Вісник ЦНЗ АПВ Харківської області.-2009.- Т. 6. - С. 131-137.

12. Коптелова, Е. К. О крахмале из восковидной кукурузы [Текст] / Е. К. Коптелова, Н. Д. Лукин, Ю. И. Третьяков //Пищевая промышленность. - 2012. - №. 4. - С. 56-58.

13. BeMiller, J. N. Starch: Chemistry and Technology [Text] / J.N. BeMiller, R.L. Whistler. -Academic Press, $2009 .-894$ p.

14. Chakraverty, A. Handbook of Postharvest Technology: Cereals, Fruits, Vegetables, Tea, and Spices [Text] / A. Chakraverty, A. S. Mujumdar, H. S. Ramaswamy. - CRC Press, 2003. -912 p.

15. Philippeau, C. Relationship between ruminal starch degradation and the physical characteristics of corn grain [Text] $/$ Philippeau C. et al. // Journal of animal science. - 1999. - vol. 77. - №. 1. - p. 238-243.

16. Ghosh, T.K. Energy Resources and Systems: Volume 2: Renewable Resources [Text] / T.K. Ghosh, M.A. Prelas. - Springer Science \& Business Media, 2011. - 727 p.

17. Домарецький, В. А. Технологія екстрактів, конщентратів і напоїв із рослинної сировини.: Підручник для ВМНЗ IIIIV p.a. [Текст] - Нова Книга. -370 c.

18. Applewhite, T. H. Proceedings of the World Congress on Vegetable Protein Utilization in Human Foods and Animal Feedstuffs [Text] / T. H. Applewhite. - The American Oil Chemists Society, 1989.

19. Zarkadas, C. G. Assessment of the protein quality of 15 new northern adapted cultivars of quality protein maize using amino acid analysis [Text] / C. G. Zarkadas et al. //Journal of agricultural and food chemistry. - 2000. - vol. 48. - №. 11. p. 5351-5361.

20. Lásztity R. Cereal Chemistry [Text] / R. Lásztity. - International Specialized Book Services, 1999. - 307 p.

21. Bajaj, Y.P.S. Maize, Biotechnology in Agriculture and Forestry [Text] / Y.P.S. Bajaj . -Springer Science \& Business Media, 2012. $-632 p$.

22. Meurant, G. Lipids in cereal technology[Text] /. Elsevier, 2012. -425 p.

23. Wrigley, C. W. Encyclopedia of food grains [Text] / C. W. Wrigley, H. Corke, K. Seetharaman, J. Faubion. - Academic Press, 2015. - $1976 \mathrm{p}$.

24. Belitz, H.-D. Food Chemistry [Text] / H.-D. Belitz,W. Grosch, P. Schieberle. - Springer Science \& Business Media, 2013. - $993 p$.

25. Kulp, K. Handbook of Cereal Science and Technology [Text] / K. Kulp. - CRC Press, 2000. - 808 p.

26. Malin, S. Starch in Food: Structure, Function and Applications [Text] / S., Malin, L. Nilsson. - Woodhead Publishing, 2017. $-916 p$.

27. Ahmed J. Novel food processing: effects on rheological and functional properties[Text] /. - CRC Press, 2016. - 510 p.

28. Inglett, G.Maize: Recent Progress in Chemistry and Technology [Text] 1. - Academic Press, 2012.- 262 p.

29. Hui Y. H., Sherkat F. Handbook of Food Science, Technology, and Engineering 4Volume Set [Text] / Y. H. Hui, F. Sherkat. - CRC Press, 2005. - 3632 p.

30. Henry, R. J. Cereal Grain Quality [Text] / R. J. Henry, P. S. Kettlewell. - London UK: Chapman and Hall, 1996. -488p.

31. Larkins, B. A. Maize Kernel Development [Text] I. - CABI, 2017. - 253 p.

32. Gwirtz, J. A. Processing maize flour and corn meal food products [Text] / J. A. Gwirtz, M. N. Garcia-Casal//Annals of the New York Academy of Sciences. - 2014. - vol. 1312. - №. 1. - p. 66-75.

33. Lasztity R. The chemistry of cereal proteins [Text] /. - Routledge, 2017. - 336 p.

34. Liu, K. Distillers Grains: Production, Properties, and Utilization [Text] / K. Liu, K. A. Rosentrater. - CRC Press, 2016. $564 \mathrm{p}$.

35. Фадеев, Л. Кукуруза. Особенности строения [Текст]. - Хранение и переработка зерна. - 2015. - T. 192. - №. 3-4. C. $41-43$.

36. Яхтанигова, Ж. М. Химический состав и питательная ценность зерна и листостебельной массы различных подвидов кукурузы [Текст]. - Новые технологии. - 2008. - №. 5.

37. Сотченко Ю. В. Исследование химического состава зерна перспективных самоопыленных линий кукурузы [Електронний ресурс]. - режим доступу: http://bibl-stgau.ru/images/Files/number29.pdf\#page=220 
38. Kulakova, E. V. Contribution to the investigation of the corn germ Part I. Corn germ as a valuable source of protein [Text] / E. V. Kulakova, E. S. Vainerman S. V. Rogoshin// Molecular Nutrition \& Food Research. - 1982. - vol. 26. - №. 5. - p. 451-456. doi.org/10.1002/food.19820260508

39. Briggs, D. E. Malts and malting [Text]. - Springer Science \& Business Media, 1998. - $796 p$.

40. Karababa, E. Physical properties of popcorn kernels. - Journal of Food Engineering. - 2006. - vol. 72. - №. 1. - p. 100107. doi:10.1016/j.jfoodeng.2004.11.028

41. Kent, N.L. Technology of cereals: an introduction for students of food science and agriculture [Text] / N.L. Kent, A.D. Evers. - Woodhead Publishing, 1994. -334 p.

42. Hallauer, A. R. Specialty Corns, Second Edition [Text] / A. R. Hallauer. - CRC Press, 2000. -496 p.

43. Scrob, S. The biochemical composition and correlation estimates for grain quality in maize [Text] / Scrob S. et al. //Journal of Agroalimentary Processes and Technologies. - 2014. - vol 20. - №. 2. - p. 150-155.

44. Шутенко С.I. Технологія круп'яного виробництва: навч. посібник / С.I. Шутенко , С.М. Соц.- К.: Освіта Украӥни, 2010. $-272 c$

45. Ray, R.C. Bioethanol Production from Food Crops: Sustainable Sources, Interventions, and Challenges [Text] / R.C. Ray, S. Ramachandran. - Academic Press, 2018. -460 p.

46. Thorne, P.J. Maize as Food, Feed, and Fertiliser in Intensifying Crop-livestock Systems in East and Southern Africa: An Ex Ante Impact Assessment of Technology Interventions to Improve Smallholder Welfare [Text]. - ILRI, 2002. - $112 \mathrm{p}$.

47. Егоров, Г.А Технология муки. Технология крупы [Текст] / Г.А. Егоров, Н.В. Куркина, Г.Ц. Цыбикова, и др. - Москва: КолосС, 2005. -296 c.

Надійшла 02.02.2019. До друку 25.02.2019.

Рецензія 10.02.2019

Адреса для переписки:

65039, Odessa, str. Kanatnaya 112

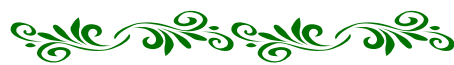

\title{
THE CHARACTERISTIC OF COMPOUND FEEDS FOR CLARIAS GARIEPINUS
}

\begin{abstract}
Abstrakt
The article states that industrial fish farming in inland waters has become increasingly important in the recent years and it is one of the sources for satisfying the needs of people in the high-protein foods. The fish meat is an extremely rich source of proteins, which are easily digested, vitamins, polyunsaturated fatty acids, macro- and microelements. One of the priorities of the development of the fish farming in Ukraine is the cultivation of the Clarias gariepinus. Clarias gariepinus or African sharptooth catfish is a species of catfish of the family Clariidae, the airbreathing catfishes. In 2017, with the support of the Ukrainian State Agency, the Institute of Fisheries of Ukraine on the part of the state and the companies Vismar Aqua, Aquaprom and the Dutch company Trouw Nutrition («Skretting»), the program was developed to increase the cultivation of the Clarias gariepinus under the name Clarias gariepinus - 2020. The objective of the program is to provide 2020 tons of Clarias gariepinus until 2020. Today, the production of the Clarias gariepinus in Ukraine is about 500 tons per year; about 50 farms are engaged in cultivation. That is why the production of balanced domestic compound feeds for Clarias gariepinus is an important task of the feed industry of Ukraine.

The theoretical study was devoted to the problem of the production of compound feeds for the Clarias gariepinus. The nutritional value of compound feeds for Clarias gariepinus a depends on the stage of the life cycle of this species of fish. The above world leaders are manufacturers of compound feeds for Clarias gariepinus, the analysis of granule size and nutritional value of compound feeds on the content of crude protein in prestarting, starting, growth and finishing periods respectively. The requirements for the content of essential and non-essential amino acids, minerals (micro and micronutrients), water and fat soluble vitamins and restrictions on the content of crude fiber are given. Indicated the main and additional raw materials, traditionally used in the manufacture of data feed advanced companies. The main components are fish meal, produced under relatively low drying conditions, wing meal, corn and wheat gluten, soy products, by-products of extraction oil and press production oil (soya, sunflower and other cakes and meals), premisex, carotenoids like astaxanthin. The feeding programs of the Clarias gariepinus of various manufacturers have been analyzed and their own feeding program has been developed for this species of fish; it divides the period of cultivation of the Clarias gariepinus into prelaunch, starting, growth and finishing ones. For prestart mixed feeds, the content of crude protein should be at least $45 \%$, raw fat at least $12 \%$, raw fiber not more than 1.8\%, gross energy not less than $13.7 \mathrm{MJ}$, raw ash not more than $8 \%$. For starter feed, the content of crude protein should be at least $42 \%$, raw fat at least $12 \%$, raw fiber not more than 3\%, gross energy not less than 13.1 MJ, raw ash not more than $9.5 \%$. For grower's feeds, the content of crude protein should be at least $38 \%$, raw fat at least $12 \%$, crude fiber not more than $3 \%$, gross energy not less than $12 \mathrm{MJ}$, raw ash not more than $9.5 \%$.

Key words: compound feed for Clarias Gariepinus or African sharptooth catfish, feed manufacture technology for Clarias Gariepinus's feeds, requirements for Clarias Gariepinus feeds.
\end{abstract}

